\title{
Banana and plantain production systems in Benin: ethnobotanical investigation, varietal diversity, pests, and implications for better production
}

Mariano C. Chabi', Anicet G. Dassou ${ }^{1 *} \mathbb{D}$, Innocent Dossou-Aminon ${ }^{1}$, David Ogouchoro',

Bonaventure Omondi $\mathrm{Aman}^{2}$ and Alexandre Dansi ${ }^{1}$

\begin{abstract}
Background: The cultivated banana and plantain (Musa spp.) are valuable for nutritional and socio-economic security for millions of people worldwide. In Benin, banana and plantain are among the most produced, consumed, and traded commodities. Its production is mainly for local consumption and remains insufficient to the demand. However, the varietal diversity of banana and plantain cultivated in Benin is not documented. This study aims at characterizing the banana and plantain cropping systems, genetic diversity, and production constraints as a baseline to the full utilization of this resource in crop improvement and to identify the potential production and agronomic qualities.
\end{abstract}

Methods: A baseline investigation of ethnobotanical attributes of banana cultivars was done in 51 randomly chosen villages in southern Benin. Interviews with randomly selected representative farmers were carried out. Key informant interviews and focus group discussions were used for global confirmatory investigation of survey data. Socio-demographic data and indigenous knowledge on the farmer uses of banana and plantain diversity, such as cultural practices, origin, and availability of banana and plantain planting materials, and the constraints and criteria of varietal preference cited by farmers were ranked.

Results: Eighty-seven locally recognized cultivars were found: 73 of banana and 14 of plantain groups. The most popular cultivars were Sotoumon (banana) (52.94\%), Aloga (plantain) (41.17\%), Planta (banana) (33.33\%), and Adjangan (plantain) (27.45\%). Of the eleven production constraints identified, the main biotic challenges were banana weevil Cosmopolites sordidus Germar and banana bunchy top virus (BBTV), while abiotic problems were drought and the wind. Some local varieties like Amandan, Assonwonnou, Coleti, and Ninkouin are extremely rare owing to agronomic and economic preference perceptions.

Conclusion and implications: This study provides a baseline for banana diversity in Benin and the West African region and entry points for biological characterization and production improvement. This would enable the exploitation of this resource for plant breeding towards biotic and abiotic challenges facing banana production.

Keywords: Banana and plantain, Ethnobotanical investigation, Constraints, Preference criteria, Cultivars, South Benin

\footnotetext{
* Correspondence: dassoua5@gmail.com

${ }^{1}$ Laboratory of Biotechnology, Genetic Resources and Plant and Animal

Breeding, National University of Sciences, Technologies, Engineering and

Mathematics, BP: 14, Dassa, Benin

Full list of author information is available at the end of the article
}

(c) The Author(s). 2018 Open Access This article is distributed under the terms of the Creative Commons Attribution 4.0 International License (http://creativecommons.org/licenses/by/4.0/), which permits unrestricted use, distribution, and reproduction in any medium, provided you give appropriate credit to the original author(s) and the source, provide a link to the Creative Commons license, and indicate if changes were made. The Creative Commons Public Domain Dedication waiver (http://creativecommons.org/publicdomain/zero/1.0/) applies to the data made available in this article, unless otherwise stated. 


\section{Background}

Banana and plantain are important food crops for millions of people worldwide. Dessert bananas are the fourth most important fruit crop in the world after grapes, citrus fruits, and apples [1]. Bananas and plantains are a staple food for more than 400 million people in the developing countries of South America, South-East Asia, and Africa and are also a key commodity in international and local trade, hence a key source of income [2]. More than 145 million tons of banana and plantain were produced worldwide in 2011 [3]. In sub-Saharan Africa, it has been estimated that banana and plantain consumption provides at least $25 \%$ of the energy needs of 70 million people. Although an introduced crop, Africa is also home to two centers of secondary diversification of Musa spp.: the East African Highland bananas (AAA-EA) in the Great Lakes region of Eastern and central Africa and Plantain in western Africa [4-6]. Banana production in the continent is therefore important for food security and continental economic productivity.

Knowledge of the genetic diversity and agro-ecological adaptation in Musa is important for the conservation and utilization of banana genetic potential to address contemporary food security needs. Morphological and agronomic characters have been widely used for clone identification and taxonomic studies [7, 8]. The varieties currently consumed are, for the most part, sterile, aspermed, and triploid clones, sometimes originating from the only Musa acuminata Colla species (AAA group) or from interspecific crosses between $M$. acuminata and M. balbisiana Colla (groups $\mathrm{AAB}$ and $\mathrm{ABB}-$ [9]). There are also diploid varieties ( $A A$ and $A B$ ) and, less commonly, tetraploid clones of interspecific origin mostly arising from breeding programs (e.g., FHIAs).

In Benin, the banana and plantain are mainly grown in the agro-ecological zones 6,7 , and 8 found in the southern part of the country. These areas have climatic and edaphic conditions favorable to banana production compared to other areas of the country where it is warmer. The total area under the crop in Benin is 20,070 ha [10]. With new agricultural policies of the Benin [11], particularly geared to agricultural diversifying or domestic and external markets, banana production has the potential to stabilize the incomes of small farmers and traders and improve the trade balance for the country.

Bananas and plantains have multiple uses in Benin. They are consumed mainly as fresh fruit, cooked or processed food items, confectionery, or alcoholic beverages. The banana pulp is dried and ground to flour for feeding the children [12,13]. Flowers of some varieties are used in traditional therapy [14]. Nevertheless, the production of bananas and plantains in Benin is mainly done under extensive subsistence systems, with low input levels or labor investment, and hence confronted with biotic and abiotic challenges. Also, little support from extension services is afforded to the banana crop [10]. Apparently, agricultural statistics for banana production have been only estimated in recent years without field assessment of the importance of production, varietal preference, and production constraints in the country. The ecological requirements of banana and the research and option needs for a development of banana production have been investigated [15]. However, little has been done to document the endogenous knowledge on banana production systems, constraints, current varietal diversity, and the varietal preference criteria and their variation across agro-ecological and ethnic zones.

This study aims to characterize the production systems of the different existing cultivars of banana and plantain to determine their diversity, production constraints, and farmer preferences criteria and hence to contribute to banana production in the region. Farmers' fields provide a rich resource in banana diversity and conservation in situ. Also, soma-clonal variation/mutations are a significant source of beneficial genetic variants in non-trueseeded crops, like banana [16]. Thus, knowledge of the existing varietal diversity is necessary as a starting point towards characterizing and documenting the existing variation $[17,18]$. Breeding programs may benefit from varietal attributes of cultivars and an evaluation of the constraints of production and farmer preference criteria [19]. Local knowledge is often rich in varietal characteristics from years of observation which might be useful in breeding and empirical comparison of varieties. This preliminary study, therefore, focuses on the ethnobotanical knowledge of the varietal diversity of banana and plantain cultivated in southern Benin where its production is high. Specifically, the present study aims to (i) document endogenous knowledge on banana and plantain cultivation, (ii) analyze existing varietal diversity and the distribution of banana and plantain cultivated in southern Benin, (iii) classify the farmer preference criteria of varieties and the constraints related to the cultivation of bananas and plantains in South Benin, and (iv) determine the level of insect pest damage and its relationship with the cultivated Musa diversity.

\section{Methods \\ Study site}

The study was carried out in 21 districts of 6 departments of southern Benin, all occurring with the main banana growing agro-ecological zones of the country (Fig. 1). This study zone is limited to the north by the region of Central Benin, to the south by the Atlantic Ocean, to the east by the Federal Republic of Nigeria, and to the west by the Republic of Togo. It is located in the Guineo-Congolese agro-ecological zone. It is the wettest area of Benin and covers an area of $17,978 \mathrm{~km}^{2}$ 


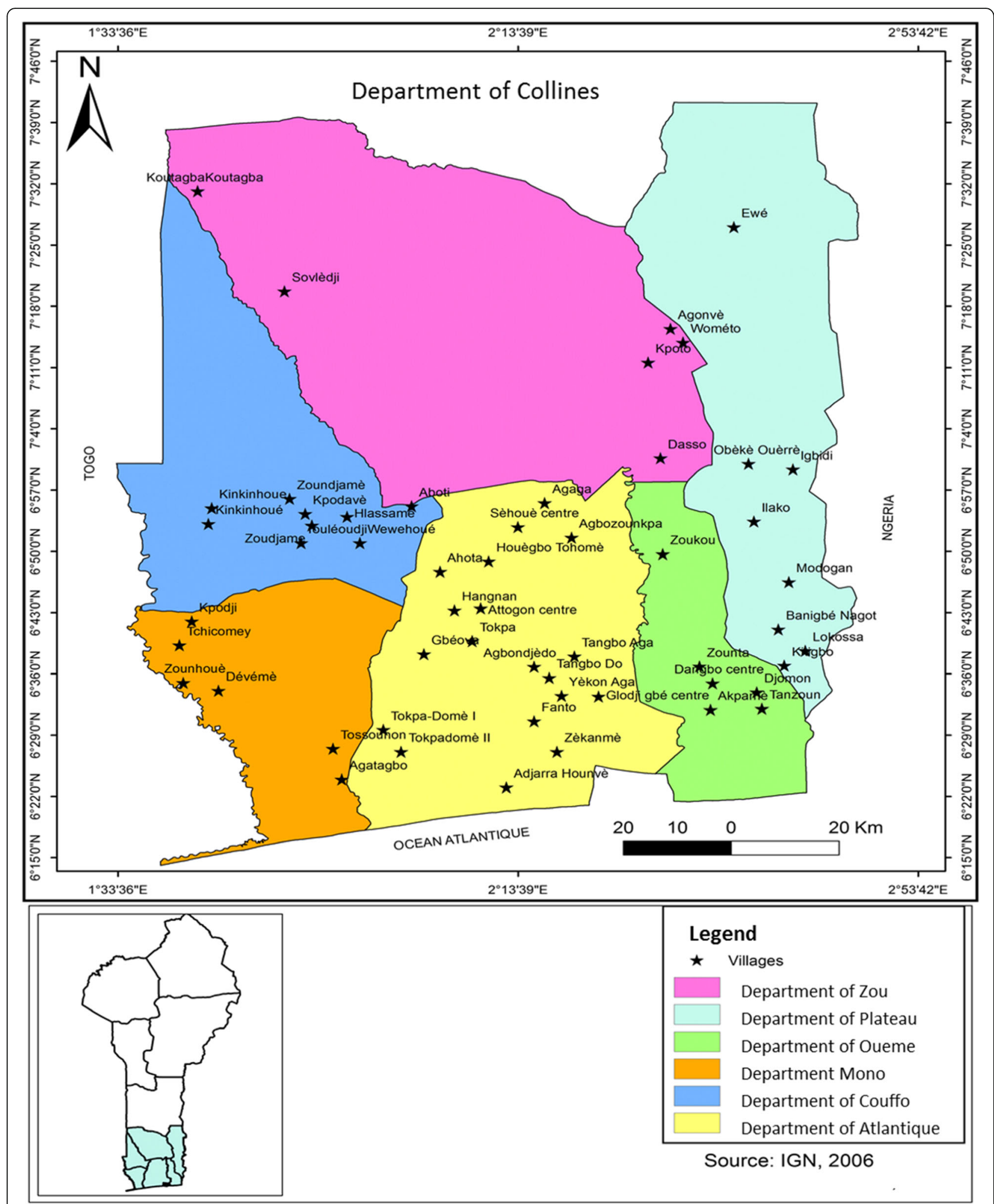

Fig. 1 Map of the studied zone. All the villages on the map were randomly selected from the study area for the data collection and in order to obtain good ethnic coverage and good diversity of local varieties of banana and plantain. The sampling was done in 2 to 3 days in each village to collect the maximum of the diversity of bananas and plantains 
Table 1 Different names used by farmers to designate banana and plantain accessions in South Benin

\begin{tabular}{|c|c|c|c|c|}
\hline Number & Cultivars & Type & $\begin{array}{l}\text { Number } \\
\text { of village }\end{array}$ & Villages \\
\hline 1 & Abidja & Plantain & 1 & Tangbo Aga \\
\hline 2 & Adjangan & Plantain & 14 & $\begin{array}{l}\text { Tokpadomèl, Dévémè, Zouhouè, Tchicomey, Kpodji, Agatogbo, Tossohon, Tangbo Aga, Glodjigbé, } \\
\text { Yèkon aga, GloFanto, Tokpadomè II, Adjarra Hounvè, Gbeova }\end{array}$ \\
\hline 3 & Agba & Plantain & 7 & Banigbé Nago, Igbidi, Lokossa, Modogan, Ewé, Obèkè Ouèrè, Agatogbo \\
\hline 4 & Agbavé & Plantain & 3 & Tchicomey, Kpodji, Kpodji \\
\hline 5 & Agoukokoué & Plantain & 1 & Kpoto \\
\hline 6 & Akodou & Banana & 1 & Dévémè \\
\hline 7 & Akokoué & Banana & 1 & Kpoto \\
\hline 8 & Akpahissi & Banana & 3 & Dévémè, Tchicomey, Kpodji \\
\hline 9 & Alladakodou & Banana & 2 & Tchicomey, Kpodji \\
\hline 10 & Allokokoué & Banana & 1 & Kpodji \\
\hline 11 & Aloga & Plantain & 21 & $\begin{array}{l}\text { Obèkè Ouèrè, Kitigbo, Kpoto, Dévémè Tchicomey, Tangbo Aga, Agbondjèdo, Attogon centre, } \\
\text { Zèkanmè, Yèkon aga, HouègboTohomè, Sèhouè centre, Agbozounkpa, Tokpadomè I, Tokpadomè Il, } \\
\text { Adjarra Hounvè, Gbéova, Tokpa, Hangnan,Ahota, Lanmadji }\end{array}$ \\
\hline 12 & Alogli & Banana & 2 & Zèkanmè, Hangnan \\
\hline 13 & Alokpoé & Banana & 1 & Tchicomey \\
\hline 14 & Amandan & Banana & 1 & Zounhouè \\
\hline 15 & Amawiti & Banana & 3 & Kpoto, Agbozounkpa, Gbeova \\
\hline 16 & Assanmiénu & Banana & 1 & Touléhoudji \\
\hline 17 & Assonwonou & Banana & 1 & Kpoto \\
\hline 18 & Atchakpoé & Banana & 1 & Dévémè \\
\hline 19 & Avlan & Plantain & 7 & Dangbo-centre, Dasso, Tanzoun, Zounta, Akpamè, Obèkè Ouèrè, Ewé \\
\hline 20 & Avlandjangn & Plantain & 1 & Tchicomey \\
\hline 21 & Chinouavi & Banana & 1 & Tossohon \\
\hline 22 & Chon & Banana & 1 & Kpoto \\
\hline 23 & Cododoé & Banana & 1 & Tchicomey \\
\hline 24 & Colèti & Banana & 1 & Kpoto \\
\hline 25 & Dangni & Banana & 1 & Akpamè \\
\hline 26 & Dankodou & Banana & 2 & Kinkinhoué, Zoundjamè \\
\hline 27 & Dankokoué & Banana & 10 & $\begin{array}{l}\text { Zoukou, Tchicomey, Kpodji, Kinkinhoué, Tangbo Aga, Zèkanmè, GloFanto, Houègbo Tohomè, } \\
\text { Tokpadomè l, Adjarra Hounvè }\end{array}$ \\
\hline 28 & Danvlan & Banana & 1 & Kpodji \\
\hline 29 & Dimangnan & Banana & 1 & Touléhoudji \\
\hline 30 & Djanvlan & Plantain & 1 & Agbozounkpa \\
\hline 31 & Djilèkè & Banana & 1 & Agbozounkpa \\
\hline 32 & Djogodjigui & Banana & 1 & Adjarra Hounvè \\
\hline 33 & Dohèzè & Banana & 6 & Zounta, Dangbo-centre, Attogon centre, Zèkanmè, GloFanto, Djomon \\
\hline 34 & Edanmandan & Banana & 1 & Zoundjamè \\
\hline 35 & Emènin Olory & Banana & 1 & Obèkè Ouèrè \\
\hline 36 & $\begin{array}{l}\text { Eminnè } \\
\text { otchoumaré }\end{array}$ & Banana & 2 & Ewé, Obèkè Ouèrè \\
\hline 37 & Eminnèré & Banana & 2 & Obèkè Ouèrè, Banigbé Nago \\
\hline 38 & Fiossiké & Banana & 1 & Zounhouè \\
\hline 39 & Flodjèguèdjèguè & Banana & 1 & Kpoto \\
\hline 40 & Fonkokoué & Banana & 1 & Kpoto \\
\hline
\end{tabular}


Table 1 Different names used by farmers to designate banana and plantain accessions in South Benin (Continued)

\begin{tabular}{|c|c|c|c|c|}
\hline Number & Cultivars & Type & $\begin{array}{l}\text { Number } \\
\text { of village }\end{array}$ & Villages \\
\hline 41 & Gangni & Plantain & 1 & Agbozounkpa \\
\hline 42 & Gangnikokoué & Plantain & 2 & Dangbo-centre, Zounta \\
\hline 43 & Gangnilo & Banana & 1 & Sèhouè centre \\
\hline 44 & Gbakokoué & Banana & 7 & Tchicomey, Tangbo Aga, Attogon centre, GloFanto, HouègboTohomè, Tokpadomè I, Tokpa \\
\hline 45 & Gbala & Plantain & 4 & Wéwéhoué, Touléhoudji, Aboti, Gnamamè \\
\hline 46 & Gbavénon & Plantain & 1 & Tchicomey \\
\hline 47 & Gbofoutou & Banana & 1 & Agbozounkpa \\
\hline 48 & Gbogui & Banana & 2 & Dangbo-centre, Akpamè \\
\hline 49 & Gnimagnan & Banana & 1 & Kpodavé \\
\hline 50 & Gnivlan & Banana & 2 & Akpamè, Tchicomey \\
\hline 51 & Goukokoué & Banana & 1 & Dangbo-centre \\
\hline 52 & Hlogui & Banana & 3 & Dangbo-centre, Djomon, Zounta \\
\hline 53 & Hohovikokoué & Banana & 1 & Tchicomey \\
\hline 54 & Houngbo & Banana & 1 & Gbéova \\
\hline 55 & Jokosso & Banana & 2 & Igbidi, Obèkè Ouèrè \\
\hline 56 & Kinkoun & Banana & 1 & Houègbo Tohomè \\
\hline 57 & Kodou & Banana & 1 & Kpodavé \\
\hline 58 & Kokodoé & Banana & 1 & Tchicomey \\
\hline 59 & Kolédo & Banana & 1 & Zounhouè \\
\hline 60 & Kouekouekoyou & Banana & 1 & Hangnan \\
\hline 61 & KouéKouéogouton & Banana & 1 & Zounta \\
\hline 62 & Kokoué & Banana & 2 & Touléhoudji, Aboti \\
\hline 63 & Koyou & Banana & 1 & \\
\hline 64 & Kpafoukpafou & Banana & 1 & Kpoto \\
\hline 65 & Kpafoutou & Banana & 2 & Sèhouè centre, Agbozounkpa \\
\hline 66 & Kpahissi & Banana & 5 & Touléhoudji, Zèkanmè, Yèkon, Tokpadomè I, Adjarra Hounvè \\
\hline 67 & Kpahounflo & Banana & 1 & Kpoto \\
\hline 68 & Kparata & Banana & 2 & Modogan, Obèkè Ouèrè \\
\hline 69 & Kpolonvi & Banana & 1 & Adjarra Hounvè \\
\hline 70 & Limonvlan & Banana & 2 & Tchicomey, Kpodji \\
\hline 71 & Malikouè & Banana & 1 & Tokpadomè I \\
\hline 72 & Mandandjoto & Banana & 1 & Touléhoudji \\
\hline 73 & Mandangan & Plantain & 7 & Wéwéhoué, Touléhoudji, Kinkinhoué, Kpodavé, Aboti, Zoundjamè, Gnamamè \\
\hline 74 & Mandankpévé & Banana & 1 & Dévémè \\
\hline 75 & Monchinonfou & Banana & 1 & Wéwéhoué \\
\hline 76 & Ninkouin & Banana & 1 & Adjarra Hounvè \\
\hline 77 & Olori & Banana & 3 & Modogan, Ewé, Obèkè Ouèrè \\
\hline 78 & Ononnon & Banana & 2 & Kpoto, Adjarra Hounvè \\
\hline 79 & Planta & Banana & 18 & $\begin{array}{l}\text { Tanzoun, Zounta, Akpamè, Dangbo-centre Zounhouè, Tchicomey, Agatogbo, Tossohon, } \\
\text { Agbondjèdo, Attogon centre, Zèkanmè, HouègboTohomè, Sèhouè centre, Sèhouè agaga, } \\
\text { Tokpadomè I, AdjarraHounvè, Ahota, Gbeova }\end{array}$ \\
\hline 80 & Sanmiénou & Banana & 1 & Gnamamè \\
\hline 81 & Sodjèmi & Banana & 2 & AdjarraHounvè, Gbeova \\
\hline 82 & Sokokoué & Banana & 2 & Dangbo-centre, Houègbo Tohomè \\
\hline
\end{tabular}


Table 1 Different names used by farmers to designate banana and plantain accessions in South Benin (Continued)

\begin{tabular}{|c|c|c|c|c|}
\hline Number & Cultivars & Type & $\begin{array}{l}\text { Number } \\
\text { of village }\end{array}$ & Villages \\
\hline 83 & Sotoumon & Banana & 27 & $\begin{array}{l}\text { Zoukou, Kitigbo, Kpoto, Dévémè, Zounhouè Tchicomey, Kpodji, Agatogbo, Tossohon, Kinkinhoué, } \\
\text { Tangbo Aga, Agbondjèdo Attogon centre, Attogon centre, Zèkanmè, Glodjigbé centre, Houègbo } \\
\text { Tohomè, Sèhouè centre, Agbozounkpa, Tokpadomè I, Tokkpadomè II, Tokpadomè I, AdjarraHounvè, } \\
\text { Gbéova, Tokpa Hangnan, Ahota }\end{array}$ \\
\hline 84 & Sovlan & Banana & 3 & Tchicomey, Hangnan, Ahota \\
\hline 85 & Tchon & Banana & 7 & Kpodji, Agbondjèdo, Attogon centre, Tokpadomè I, Tokpa, Hangnan, Gbeova \\
\hline 86 & Tokpovi & Banana & 1 & Dévémè \\
\hline 87 & Vlandjangan & Plantain & 1 & Tchicomey \\
\hline
\end{tabular}

with a population of 3684.031 , representing $30 \%$ of arable land, $40 \%$ of settlement of the whole country, and $90 \%$ of the banana zone. The per capita land holding is 0.5 ha. Benin is subdivided into four agro-ecological zones and soil qualities: coastal, Pobe, Oueme valley, and plateau [20]. The agro-ecological zone of South Benin is characterized by a bimodal rainfall with an annual average of $1200 \mathrm{~mm}$; the average temperature varies between 25 and $29^{\circ} \mathrm{C}$ and the relative humidity between 69 and 97\% [21]. The soils are of several types, of mainly hydromorphic soil, bare grounds (on continental edge) which are for the most part degraded, very deep clay soils, and humus, often hydromorphic soils. In these areas, the vegetation is variable: remnant forest, dense shrubby thickets dominated by grasses, grassy savannah, swampy raffia palm formations, and some mangrove. The crops cultivated in these areas are maize, cowpeas, cassava, market garden crops, and bananas and plantains.

\section{Ethnobotanical investigation and cultivated Musa diversity sampling}

Fifty-one villages were randomly selected from the study area in order to obtain a large ethnic coverage. Initial key informant interviews (KII) [22] were carried out in each village, with the head of the village to whom we had explained the interest of our study for their community, to obtain basic information and contacts of eventual study households. Information from this KII was used to optimize the survey tools and guidelines for the focus group discussions. In total, 151 individuals including 38 women were surveyed in the study area. Later, a total of 51 non-sex-disaggregated focus group discussions consisting of 10 individuals per group were held,

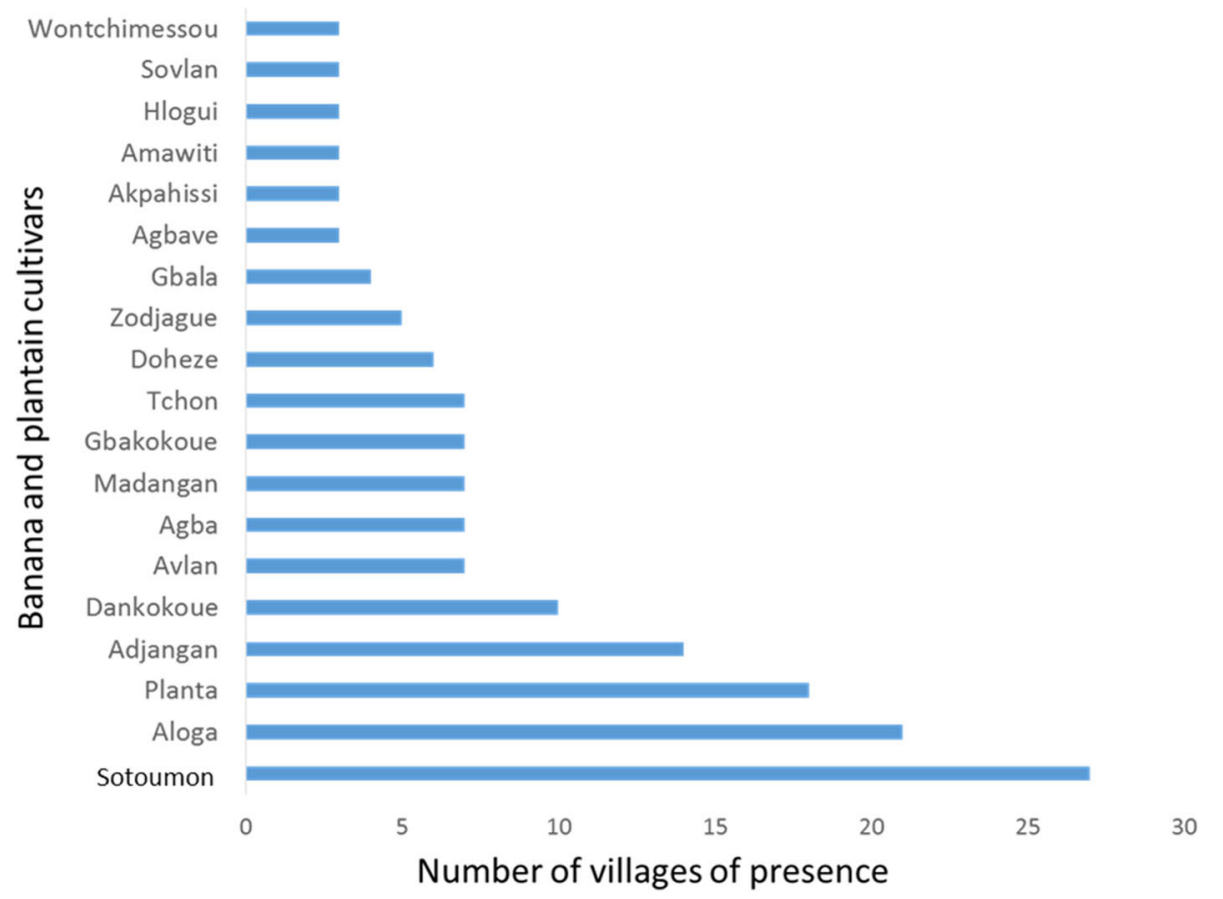

Fig. 2 Banana and plantain cultivars most collected in the villages 
Table 2 Distribution and extension of local varieties of banana and plantain collected

\begin{tabular}{|c|c|c|c|}
\hline Numero & Local varieties & Type & Villages, Distribution and extension \\
\hline 01 & Abidja & Plantain & Tangbo Aga (- -) \\
\hline 02 & Adjangan & Plantain & $\begin{array}{l}\text { Tokpadomèl }(+-) \text {, Dévémè }(+-) \text {, Zouhouè }(++) \text {, Tchicomey }(--) \text {, Kpodji }(--) \text {; Agatogbo }(+-) \text {, Tossouhon } \\
(++) \text {, Tangbo Aga }(-+) \text {, Glodjigbé }(--) \text {, Yèkon aga }(--) \text {, GloFanto }(+-) \text {, Tokpadomè II }(++) \text {, Adjarra Hounvè } \\
(++) \text {, Gbeova }(-+)\end{array}$ \\
\hline 03 & Agba & Plantain & Banigbé Nago $(--)$, Igbidi $(+-)$, Lokossa $(-+)$, Modogan $(--)$, Ewé $(-+)$, Obèkè Ouèrè $(--)$, Agatogbo $(--)$ \\
\hline 04 & Agbavé & Plantain & Tchicomey $(+-)$, Kpodji (+ -) \\
\hline 05 & Agoukokoué & Plantain & Kpoto $(+-)$ \\
\hline 06 & Akodou & Banana & Dévémè (- -) \\
\hline 07 & Akokoué & Banana & Kpoto $(-+)$ \\
\hline 08 & Akpahissi & Banana & Dévémè $(-+)$, Tchicomey $(--)$, Kpodji $(+-)$ \\
\hline 09 & Alladakodou & Banana & Tchicomey $(--)$, Kpodji $(+-)$ \\
\hline 10 & Allokokoué & Banana & Kpodji (+ -) \\
\hline 11 & Aloga & Plantain & $\begin{array}{l}\text { Obèkè Ouèrè }(+-) \text {, Kitigbo }(--) \text {, Kpoto }(--) \text {, Dévémè }(+-) \text { Tchicomey }(+-) \text {, Tangbo Aga }(--) \text {, } \\
\text { Agbondjèdo }(--) \text {, Attogon centre }(+-) \text {, Zèkanmè }(-+) \text {, Yèkon aga }(+-) \text {, Houègbo Tohomè }(+-) \text {, } \\
\text { Sèhouè centre }(--) \text {, Agbozounkpa }(+-) \text {, Tokpadomè I }(++) \text {, Tokpadomè } \|(+-) \text {, Adjarra Hounvè } \\
(+-) \text {, Gbéova }(+-) \text {, Tokpa }(--) \text {, Hangnan }(--), 12 \text { Ahota }(--) \text {, Lanmadji }(--)\end{array}$ \\
\hline 12 & Alogli & Banana & Zèkanmè $(--)$, Hangnan $(--)$ \\
\hline 13 & Alokpoé & Banana & Tchicomey $(+-)$ \\
\hline 14 & Amandan & Banana & Zounhouè (- -) \\
\hline 15 & Amawiti & Banana & Kpoto (- -), Agbozounkpa $(-+)$, Gbeova $(--)$ \\
\hline 16 & Assanmiénu & Banana & Touléhoudji (- -) \\
\hline 17 & Assonwonou & Banana & Kpoto $(--)$ \\
\hline 18 & Atchakpoé & Banana & Dévémè (- -) \\
\hline 19 & Avlan & Plantain & Dangbo-centre $(--)$, Dasso, Tanzoun $(--)$, Zounta $(+-)$, Akpamè $(-+)$, Obèkè Ouèrè $(-+)$, Ewé( --$)$ \\
\hline 20 & Avlandjangn & Plantain & Tchicomey $(+-)$, Dangbo-centre $(--)$, Dasso, Tanzoun $(--)$, Zounta $(+-)$, Akpamè $(-+)$, Obèkè \\
\hline 21 & Chinouavi & Banana & Tossouhon $(--)$ \\
\hline 22 & Chon & Banana & Kpoto $(--)$ \\
\hline 23 & Cododoé & Banana & Tchicomey $(--)$ \\
\hline 24 & Colèti & Banana & Kpoto $(--)$ \\
\hline 25 & Dangni & Banana & Akpamè $(--)$ \\
\hline 26 & Dankodou & Banana & Kinkinhoué $(--)$, Zoundjamè (+ -) \\
\hline 27 & Dankokoué & Banana & $\begin{array}{l}\text { Zoukou }(+-) \text {, Tchicomey }(--) \text {, Kpodji }(++) \text {, Kinkinhoué }(+-) \text {, Tangbo Aga }(-+) \text {, Zèkanmè }(-+) \text {, GloFanto } \\
(-28+) \text {, Houègbo Tohomè }(+-) \text {, Tokpadomè I }(+-) \text {, Adjarra Hounvè }(+-)\end{array}$ \\
\hline 28 & Danvlan & Banana & Kpodji $(--)$ \\
\hline 29 & Dimangnan & Banana & Touléhoudji (- -) \\
\hline 30 & Djanvlan & Plantain & Agbozounkpa (- -) \\
\hline 31 & Djilèkè & Banana & Agbozounkpa $(-+)$ \\
\hline 32 & Djogodjigui & Banana & Adjarra Hounvè (- -) \\
\hline 33 & Dohèzè & Banana & Zounta (- -), Dangbo-centre(- +), Attogon centre $(--)$, Zèkanmè $(-+)$, GloFanto $(-+)$, Djomon $(--)$ \\
\hline 34 & Edanmandan & Banana & Zoundjamè $(--)$ \\
\hline 35 & Emènin Olory & Banana & Obèkè Ouèrè (- -) \\
\hline 36 & Eminnè otchoumaré & Banana & Ewé, Obèkè Ouèrè (- -) \\
\hline 37 & Eminnèré & Banana & Obèkè Ouèrè $(--)$, Banigbé Nago $(--)$ \\
\hline 38 & Fiossiké & Banana & Zounhouè $(--)$ \\
\hline 39 & Flodjèguèdjèguè & Banana & Kpoto $(--)$ \\
\hline 40 & Fonkokoué & Banana & Kpoto (- -) \\
\hline
\end{tabular}


Table 2 Distribution and extension of local varieties of banana and plantain collected (Continued)

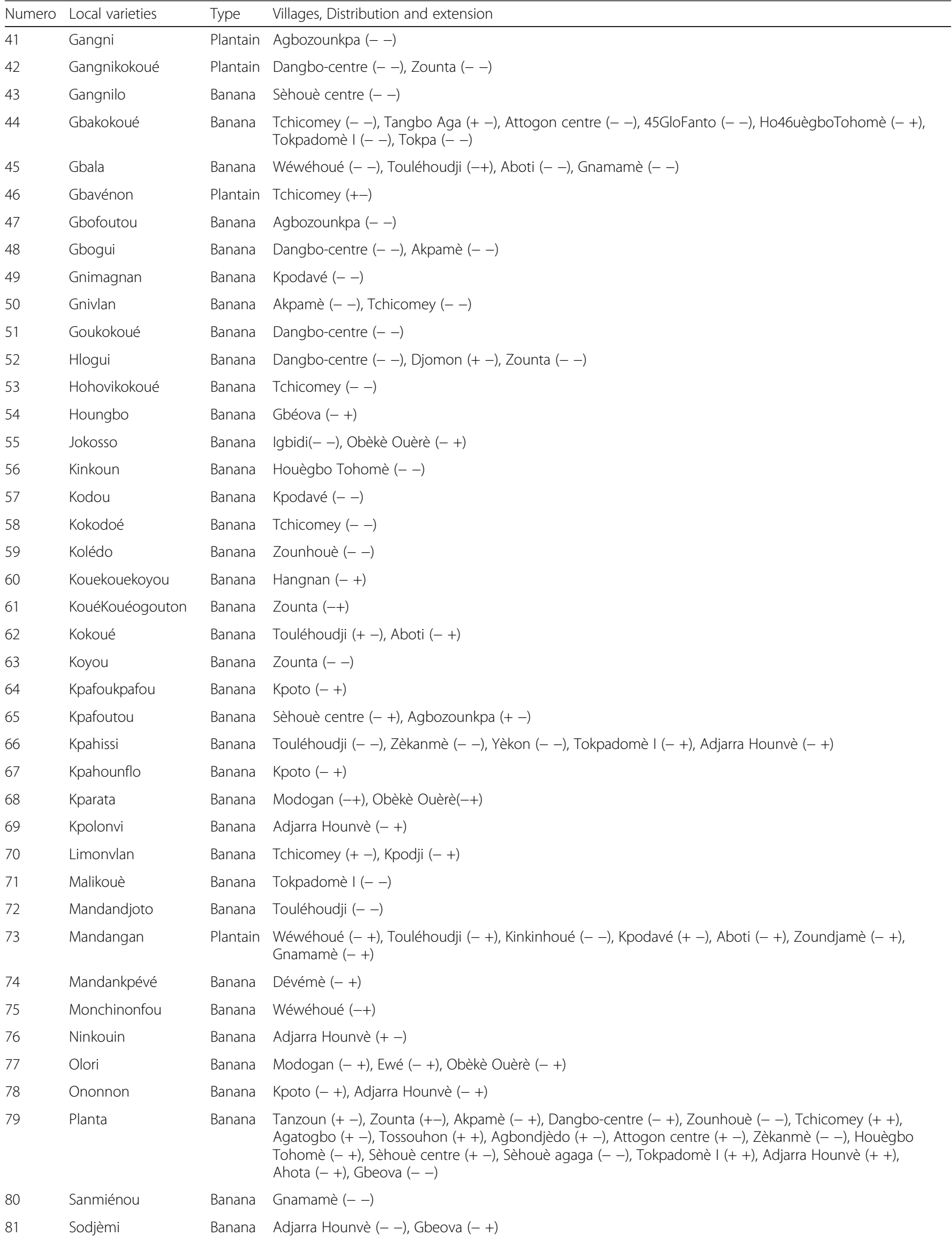


Table 2 Distribution and extension of local varieties of banana and plantain collected (Continued)

\begin{tabular}{|c|c|c|c|}
\hline Numero & Local varieties & Type & Villages, Distribution and extension \\
\hline 82 & Sokokoué & Banana & Dangbo-centre (- -); Houègbo Tohomè (- -) \\
\hline 83 & Sotoumon & Banana & $\begin{array}{l}\text { Zoukou }(++) \text {, Kitigbo }(+-) \text {, Kpoto }(++) \text {, Dévémè }(-+) \text {, Zounhouè }(-+) \text {, Tchicomey }(++) \text {, Kpodji }(++) \text {, } \\
\text { Agatogbo }(++) \text {, Tossouhon }(++) \text {, Kinkinhoué }(++) \text {, Tangbo Aga }(+-) \text {, Agbondjèdo }(++) \text { Attogon centre } \\
(-+) \text {, Zèkanm }(+-) \text {, 8Glodjigbé centre }(+-) \text {, Houègbo Tohomè }(+-) \text {, Sèhouè centre }(++) \text {, Agbozounkpa } \\
(++) \text {, Tokpadomè }(+(+) \text {, Tokkpadomè II }(++) \text {, Adjarra Hounvè }(+-) \text {, Gbéova }(++) \text {, Tokpa }(-+) \text {, Hangnan } \\
(+-) \text {, Ahota }(-+)\end{array}$ \\
\hline 84 & Sovlan & Banana & Tchicomey $(-+)$, Hangnan $(-+)$, Ahota $(--)$ \\
\hline 85 & Tchon & Banana & $\begin{array}{l}\text { Kpodji }(--) \text {, Agbondjèdo }(--) \text {, Attogon centre }(--) \text {, Tokpadomè I }(--) \text {, Tokpa }(--) \text {, Hangnan } \\
(--) \text {, Gbeova }(--)\end{array}$ \\
\hline 86 & Tokpovi & Banana & Dévémè (- -) \\
\hline 87 & Vlandjangan & Plantain & Tchicomey $(++)$ \\
\hline
\end{tabular}

+- : varieties produced by many households in small areas; - +: varieties produced by few households over large areas; - -: varieties produced by few households on small areas; + +: varieties produced by many households over large areas

one per village. Social and demographic data and endogenous knowledge on the farmer uses of banana and plantain diversity such as cultural practices, origin and availability of banana and plantain planting materials, and the constraints and criteria of varietal preference cited by farmers were ranked according to Kumar [23] and Dansi et al. [24] by identifying and progressively eliminating the most severe constraint or the most preferred traits. Farmer demographic characteristics, region, and ethnic origin were tested as possible sources of preferences. The method of prioritization was to establish the response percentage calculated on the basis of individual surveys. Samples of local varieties identified through the villages were collected from farmers. The vernacular name, the village of collection, the name of the farmer, the name of the collector, the date of collection, etc. have been documented to establish the identification data for each accession in order to set a mini national collection for Musa spp. In focus groups, the cultivars of bananas and plantains were classified into different groups according to their culinary and agronomic characteristics and key preference attributes.

\section{Survey of pest damage levels}

Data was collected on the major field pests of banana and plantain reported by each farmer. Direct observations of pests and the damage levels were also made in the field. Some of the damage noted included streaks on leaves, dark streaks on the pseudostem leaf size, and morphology [25]. The damages of the banana weevil

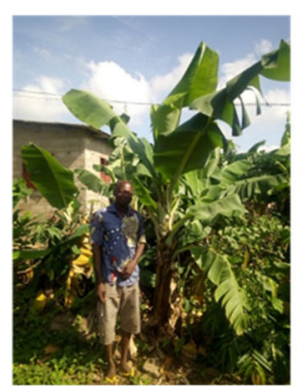

P1

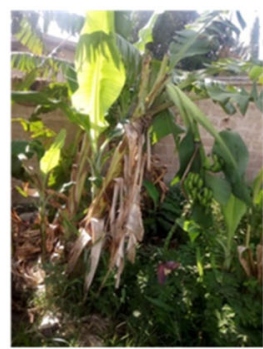

B1

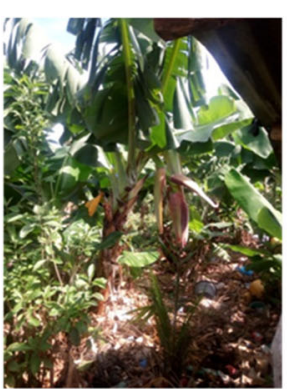

P2

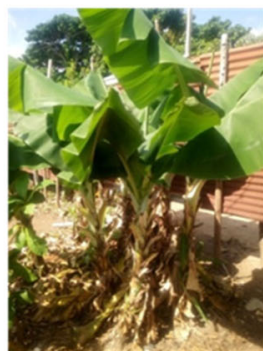

B2

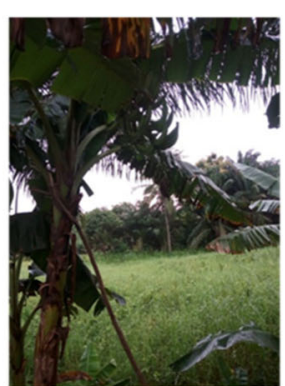

P3

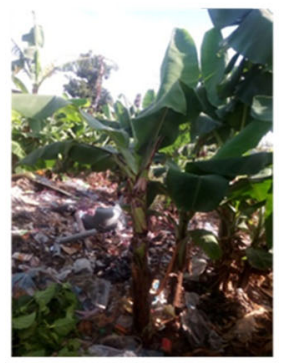

B3

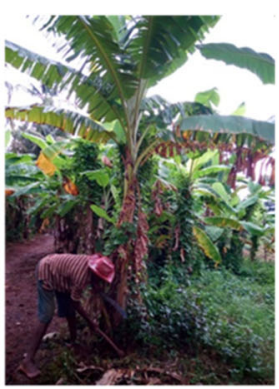

P4

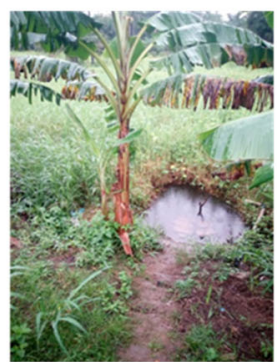

B4

Fig. 3 Shannon diversity index of districts cultivating the banana and plantain in southern Benin 


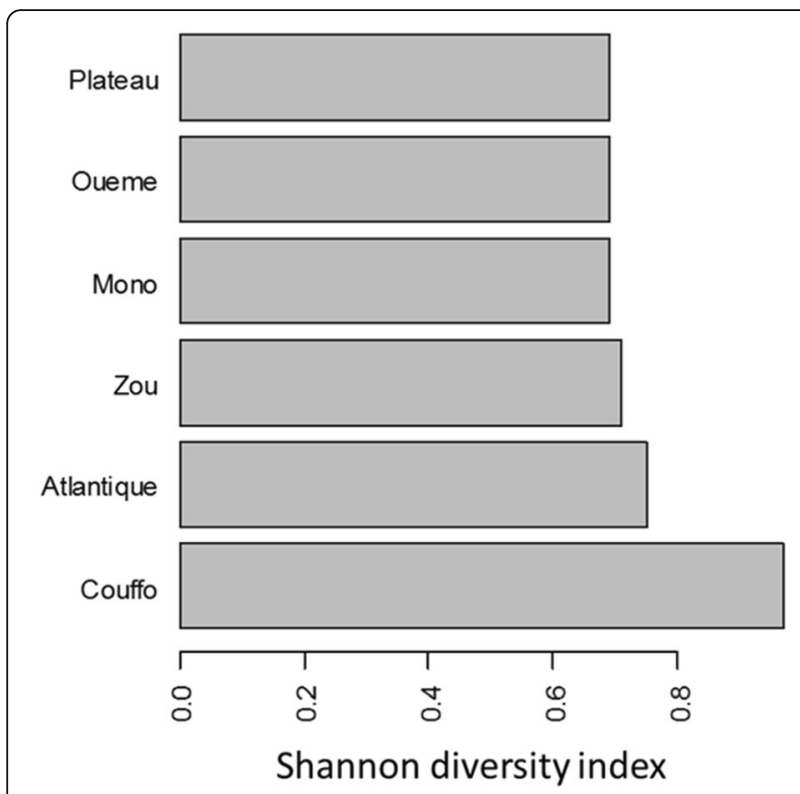

Fig. 4 Some pictures of varieties of bananas and plantains cultivated in southern Benin. P1 Plantain Mandangan. P2 Plantain Avlandjangan. P3 Plantain Aloga. P4 Plantain Adjangan. B1 Banana Planta. B2 Banana Doheze. B3 Banana Dankokoue. B4 Banana Sotoumon

were also observed on the Musa pseudostem to evaluate its importance. The following damage rating scale has been proposed [26] to evaluate the importance of damages of two major banana pests: 1 = no damage, 2 = no significant damage, $3=$ very low damage, $4=$ low damage, $5=$ mean damage, $6=$ high sensitivity damage, $7=$ high damage, $8=$ very high damage, and $9=$ severe damage (totally

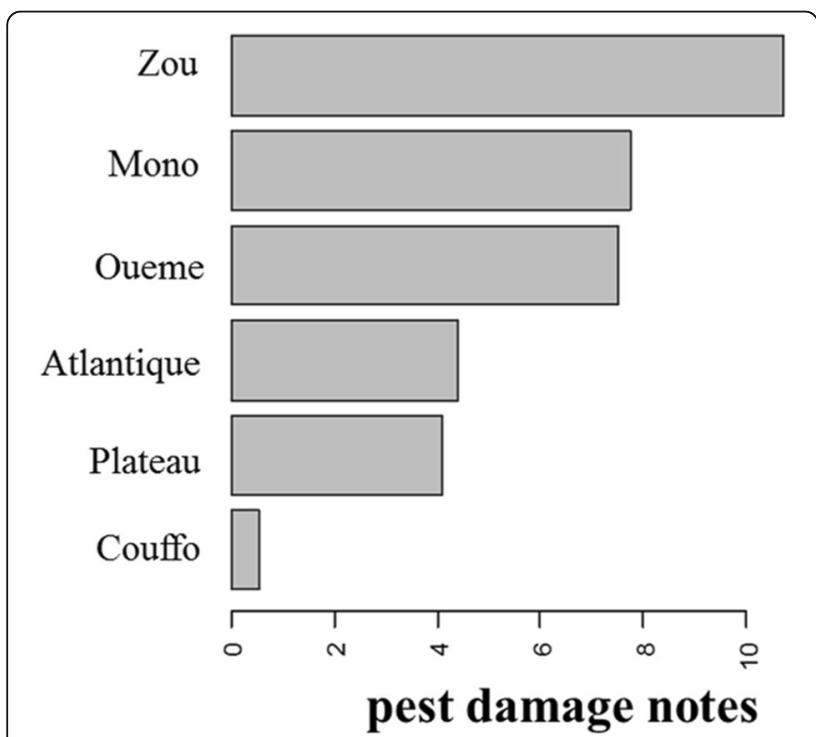

Fig. 5 Pest damage levels according to the departments of southern Benin. The average of pest damage notes is presented per department in order to understand the department that has high pest damage levels susceptible). The level of damage or infestation on banana and plantain plants by BBTD and banana weevil at the department scale was the average of the different scores attributed to disease symptoms observed in fields in the department.

\section{Data analyses}

The data of production constraints, preference criteria, local variety nomenclature, varietal losses reasons, and selling prices were summarized as descriptive statistics. Variation of banana and plantain uses according to ethnic groups was then inferred. Cultivated Musa diversity was assessed with the Shannon index [27], which was calculated with "diversity" function of the "VEGAN" package, version 2.2.1 [28]. Generalized linear models (GLMs) were used to examine the effect of the cultivated Musa diversity on pest damages. Also, GLMs also were used to test the diversity of cultivated Musa based on production villages. A dendrogram was used to classify the plantain cultivars in groups according the importance of their production. All statistical analyses were performed with $\mathrm{R}$ version 3.1 .0 [29] at the significance level of $5 \%$.

\section{Results}

Socio-demographic characteristics of both banana and plantain farmers

A total of 151 producers, 113 men and 38 women, were surveyed. Most of the farmers surveyed were in the age groups 31-60 years (average 45 years). More than half (51.65\%) of the surveyed farmers attained primary school education or lower or say did not attain any formal education. The fields ranged approximately from 100 to $10,000 \mathrm{~m}^{2}$ with an average of about $2000 \mathrm{~m}^{2}$, with a majority of the farmers owning between 100 and $2000 \mathrm{~m}^{2}$.

\section{Varietal diversity and local names of banana and plantain in South Benin}

At total, 87 cultivars of banana and plantain were identified in the 51 surveyed villages (Table 1). Of the 87 cultivars, 14 were plantain against 73 banana cultivars. Plantain cultivars Aloga (cultivated in 21 villages), Adjangan (cultivated in 14 villages), and Mandangan (cultivated in 7 villages) are the most widespread in the study area. Plantain cultivars such as Gangni, Djanvlan, and Vlandjangan were rare and found in only one village. These varieties have attributes of strong bunches but weakness distribution. The most popular banana cultivars in South Benin are Sotoumon, Planta, and Dankokoue (Fig. 2). By contrast, banana cultivars such as Amandan, Assonwonnou, Tchon, Coleti, and Ninkouin were collected only in one village each and hence very rare (Table 2). Among the six departments surveyed, Couffo included the highest cultivated Musa diversity index followed by Atlantique and Zou while Mono, Oueme, and Plateau had the lowest cultivated 


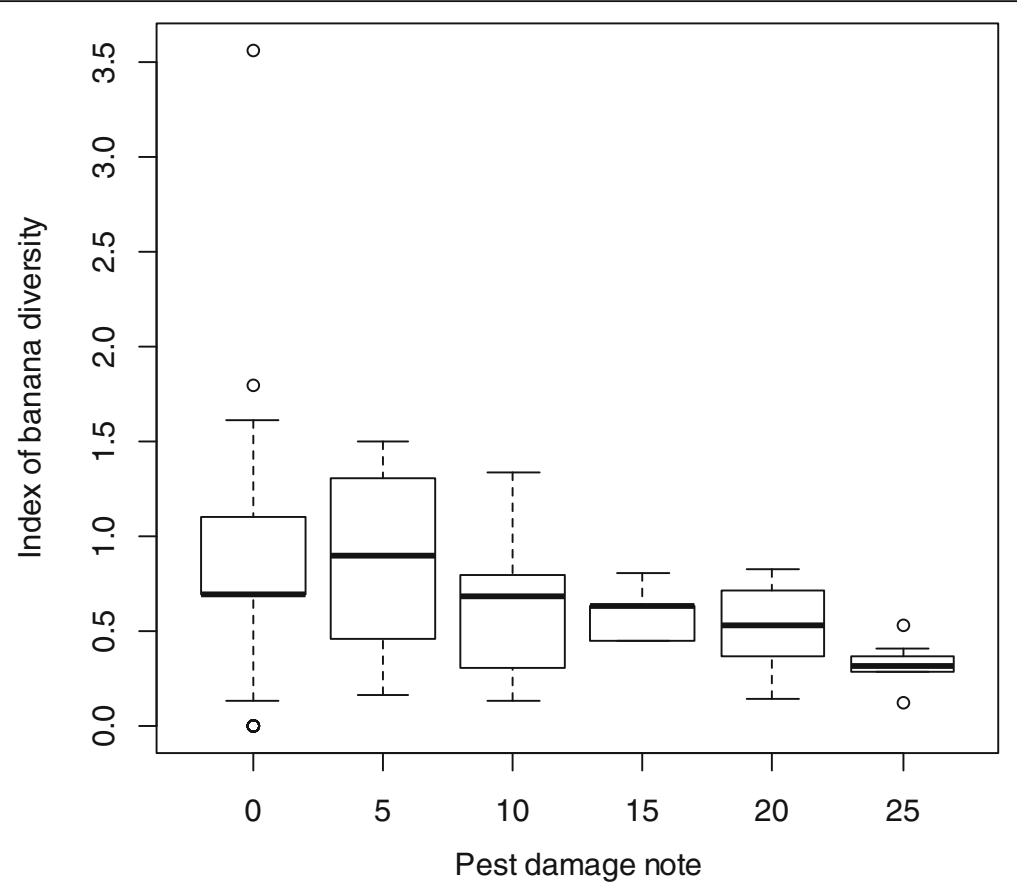

Fig. 6 Relationship between cultivated Musa diversity index and pest damage notes. The test of correlation of Kendall showed a strong negative significant correlation between the banana diversity index and pest damage notes $(Z=-3.543, P=0.0003957$, Tau $=-0.2278909)$. The low pest damage notes were linked to the high banana diversity index

Musa diversity index (Fig. 3). There was a significant difference across study departments for the cultivated Musa diversity $(P=0.02 ; \mathrm{df}=5)$. Following the survey, 275 banana accessions and 57 plantain accessions (Fig. 4) were collected in the villages surveyed for the establishment of a mini collection of Musa spp. in our experimental site for subsequent on-farm evaluation.

\section{Relationship between the cultivated Musa diversity and pest damages}

In the study zone, $100 \%$ of farmers identified banana weevil as major insect pest and banana bunchy top virus (BBTV) as major disease. Amongst the six departments surveyed, Couffo with high cultivated Musa also reported lowest pest damage followed by Plateau and Atlantique (Fig. 5). In addition, the pest damage score significantly varied between studied villages $(P<0.00001 ; \mathrm{df}=49)$. The cultivated Musa diversity was significantly negatively correlated with the pest damage score $(Z=-3.543, \quad P=0.0003957$, $\mathrm{Tau}=-0.2278909)$ (Fig. 6).

\section{Analysis of the geographical distribution of local varieties of banana and plantain}

In the study area, the local varieties of banana and plantain encountered do not have the same distribution. Thus, the local variety Adjangan (plantain) cultivated in Zouhoue, Tossouhon, and Tokpadome II by many households and over large areas was only cultivated by few households over small acreages in Kpodji, Glodjigbe, and Yekon Aga. This same cultivar was cultivated in Tokpadome I, Deveme, Agatogbo, and Glo Fanto by many households and on large surface. This same local variety was cultivated by few households and over a large Tangbo Aga area. In addition, the cultivar Sotoumon had a wide distribution and was cultivated in the majority of the villages surveyed. In all the villages where this cultivar has been cultivated, it was present in many households and cultivated over large areas. On the other hand, some cultivars such as Akodou, Chinouavi, Akokoue, and Agoukokoue (plantain) were only cultivated in one village each (Fig. 7).

\section{Farmer preference criteria of varieties of cultivated bananas and plantains}

Eleven farmer preference criteria for cultivars were identified for the selection of banana and plantain cultivars. These criteria can be grouped into four different categories (agronomic, economic, culinary, traditional, and therapeutic). The agronomic criteria (high productivity, early maturity, mature bunch size) were the most used in evaluating cultivars, with a rate of mention of $59.71 \%$. The economic criteria (high market value, smell of mature fruit, and color of the fruit at maturity) were mentioned $17 \%$ of the time. The culinary criteria (good cooking quality, good taste) and therapeutic criteria (energy rich, medicinal and cultural use) were the least 


\begin{tabular}{|c|c|}
\hline $\begin{array}{l}\text { Numerous households and large } \\
\text { areas }(+;+)\end{array}$ & $\begin{array}{c}\text { Numerous households and small } \\
\text { areas }(+;-)\end{array}$ \\
\hline $\begin{array}{l}\text { Sotoumon ; Planta ; Dankokoue ; } \\
\text { Dohèzè }\end{array}$ & $\begin{array}{c}\text { Gbofoutou ; Gnimagnan ; Hlogui ; } \\
\text { Malikouè ; Ninkouin }\end{array}$ \\
\hline $\begin{array}{c}\text { Few households and large areas }(-; \\
+)\end{array}$ & $\begin{array}{l}\text { Few households and small areas } \\
\qquad(-;-)\end{array}$ \\
\hline $\begin{array}{c}\text { Akodou ; Alladakodou ; Ononnon; } \\
\text { Mandankpévé }\end{array}$ & $\begin{array}{c}\text { Chon ; Kinkoun ; Fonkokoue ; } \\
\text { Edanmandan ; Jokosso }\end{array}$ \\
\hline
\end{tabular}

A Bananas cultivars

\begin{tabular}{|c|c|}
\hline $\begin{array}{c}\text { Numerous households and large } \\
\text { areas }(+;+)\end{array}$ & $\begin{array}{c}\text { Numerous households and small } \\
\text { areas (+ ; -) }\end{array}$ \\
\hline $\begin{array}{c}\text { Adjangan ; Aloga ; Mandangan ; } \\
\text { Avlandjangan }\end{array}$ & Gbavenon; Agoukokoué ; Agbavé \\
\hline $\begin{array}{l}\text { Few households and large areas } \\
\qquad(-;+)\end{array}$ & $\begin{array}{l}\text { Few households and small areas } \\
\qquad(-;-)\end{array}$ \\
\hline Abidja ; Gangni ; Djanvlan & Gangnikokoue ; Gbavenon \\
\hline
\end{tabular}

B Plantains cultivars

Fig. 7 Four square chart showing the distribution of local varieties of banana and plantain according to the farmer's household size and the production areas. a Local varieties of bananas. $\mathbf{b}$ Local varieties of plantains

High fruit number

Fruit colour at maturity

Traditional values

Energetic

Good food processing

Smell of fruits

Big regime and fruits

Good taste

Short cycle

High market value

High productivity

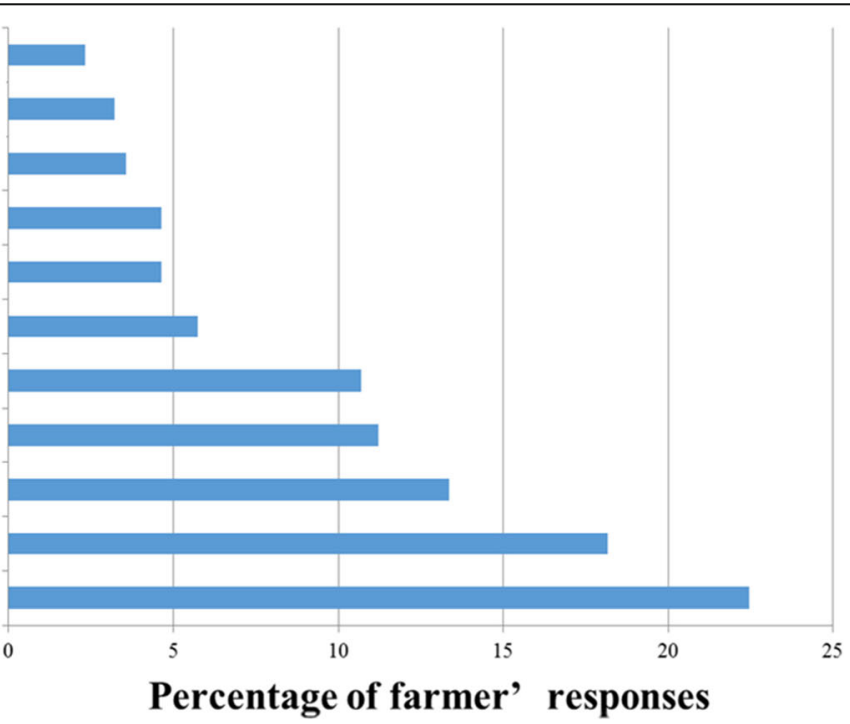

Fig. 8 Farmer's preference criteria of both banana and plantain cultivars 
Table 3 Farmer preference criteria of banana and plantain cultivars according to different ethnic groups

\begin{tabular}{llllllllllll}
\hline Criteria & Kotafon & Aizo & Adja & Yorouba & Fon & Pedah & Sahoue & Watchi & Holli & Tchi & Goun \\
\hline High market value & 20.24 & 12.64 & 22.2 & 26.7 & 22.73 & 16.6 & 23.81 & 21.43 & 33.33 & 33.3 & 18.87 \\
High productivity & 27.38 & 31.03 & 27 & 20 & 27.27 & 27.78 & 23.81 & 28.57 & 33.33 & 33.3 & 22.64 \\
Big regime and big fruits & 1.19 & 3.45 & 3.17 & 6.7 & 3.64 & 2.78 & 4.76 & 0 & 0 & 0 & 3.77 \\
Good taste & 14.29 & 16.09 & 9.52 & 3.3 & 8.18 & 13.89 & 14.29 & 21.43 & 0 & 0 & 15.09 \\
Good food processing & 15.48 & 14.94 & 15.9 & 16.7 & 13.64 & 19.44 & 4.76 & 14.29 & 33.33 & 0 & 18.87 \\
Short cycle & 5.95 & 0 & 3.17 & 0 & 2.73 & 8.33 & 0 & 0 & 0 & 0 & 0 \\
Energy rich & 5.95 & 12.64 & 9.52 & 3.3 & 8.18 & 5.56 & 4.76 & 0 & 0 & 33.3 & 9.43 \\
High number of fruits per regime & 8.33 & 6.9 & 3.17 & 3.3 & 7.27 & 0 & 4.76 & 0 & 0 & 0 & 5.66 \\
Flavor of mature fruits & 1.19 & 1.15 & 1.59 & 3.3 & 0.91 & 0 & 0 & 0 & 0 & 0 & 0 \\
Medicinal and traditional & 0 & 1.15 & 0 & 3.3 & 1.82 & 2.78 & 4.76 & 0 & 0 & 0 & 1.89 \\
Fruit color at maturity & 0 & 0 & 4.76 & 13.3 & 3.64 & 2.78 & 14.29 & 14.29 & 0 & 0 & 3.77 \\
\hline
\end{tabular}

considered, with a respective mention rate of 15.85 and $8.19 \%$ of responses (Fig. 8).

The level of preference of banana and plantain varied greatly across ethnic areas $(P<0.0001)$ (Table 3$)$ which have a strong positive correlation (Fig. 9). Some ethnic groups such as the Tchi, Holli, and Yoruba people grow banana and plantain because of its high market value. The Holli, the Tchi, the Aizo, and the Watchi preferred banana cultivation because of its high productivity with big bunch for the market. Concerning culinary aspects, in South Benin, the Holli, the Pedah, and the Goun were more in the processing of banana fruits into commercial products such as banana chips. Therapeutically, the Tchi, Aizo, and Adja use more banana and plantain.

\section{Participatory farmer's classification of banana and plantain cultivars}

During the focus group discussion of farmers, the cultivars of bananas and plantains were classified according to the agronomic, culinary, and processing characteristics (Table 4). The use of the 11 variables (Fig. 10) allowed us to group the 14 banana plantain cultivars into:

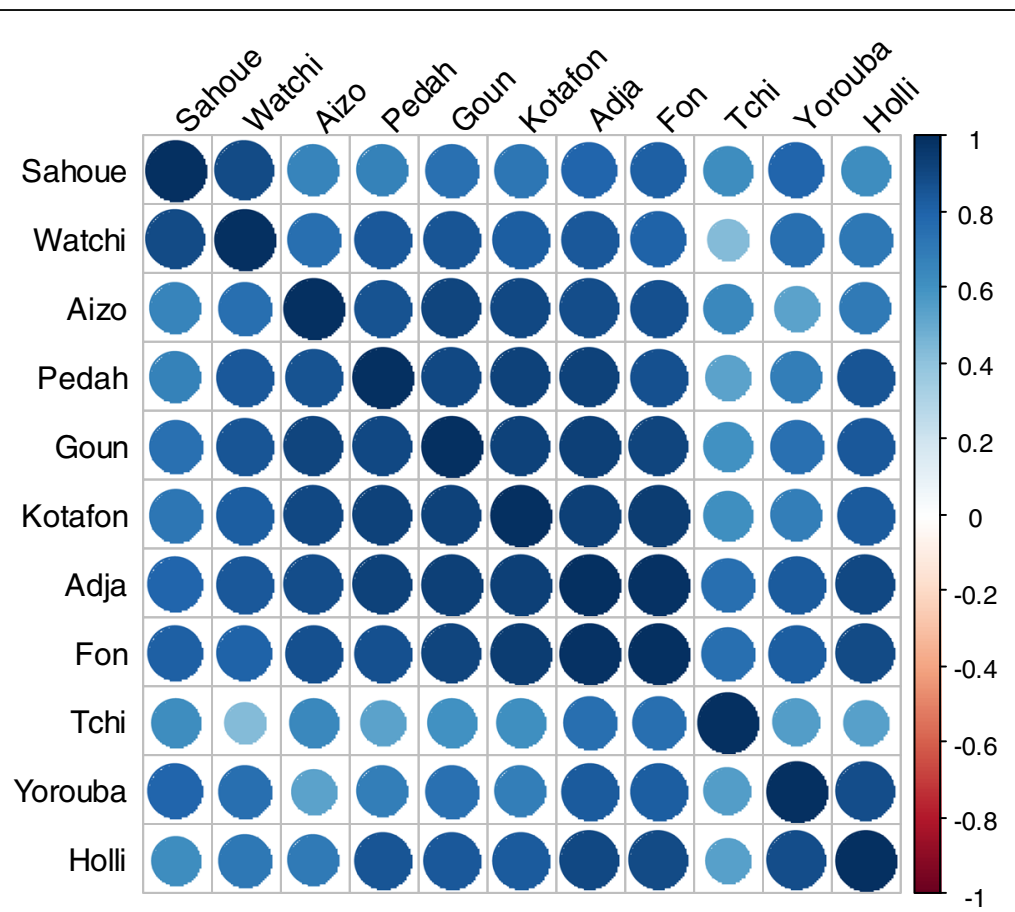

Fig. 9 Correlation between the ethnic groups according to preferences criteria of banana and plantain cultivars. Positive correlations are displayed in blue and negative correlations in red. The intensity of the color and the size of the circles are proportional to the correlation coefficients. On the right of the correlogram, the color legend shows the correlation coefficients and the corresponding colors 
Table 4 Farmer's classification of cultivars according to their characteristics

\begin{tabular}{|c|c|c|c|c|c|c|c|}
\hline \multirow[t]{2}{*}{ Cultivars } & \multicolumn{7}{|l|}{ Characteristics } \\
\hline & $\begin{array}{l}\text { Good } \\
\text { productivity }\end{array}$ & Good conservation & Short cycle & $\begin{array}{l}\text { Resistant to } \\
\text { drought }\end{array}$ & Good cooking & $\begin{array}{l}\text { Good } \\
\text { processing }\end{array}$ & Resistant to pests \\
\hline Bananas & $\begin{array}{l}\text { Sotoumon, } \\
\text { Planta, } \\
\text { Dankokoué, } \\
\text { Gbofoutou, Colèti }\end{array}$ & $\begin{array}{l}\text { Akokoué, Akodou, } \\
\text { Sotoumon, Planta, } \\
\text { Tokpovi }\end{array}$ & $\begin{array}{l}\text { Ononnon, } \\
\text { Tchon, Sovlan, } \\
\text { Alogli, } \\
\text { Assonwonnou }\end{array}$ & $\begin{array}{l}\text { Amawiti, } \\
\text { Chinouavi, } \\
\text { Chon, Planta, } \\
\text { Sanmiénou }\end{array}$ & $\begin{array}{l}\text { Planta, } \\
\text { Wontchimèssou, } \\
\text { Dohèzè, Djilékè, } \\
\text { Dankodou }\end{array}$ & $\begin{array}{l}\text { Akpahissi, } \\
\text { Alladakodou, } \\
\text { Planta, Gbala, } \\
\text { Gbogui }\end{array}$ & $\begin{array}{l}\text { Colèti, Dankokoué, } \\
\text { Fiossiké; Eminnèré, } \\
\text { Olori, Ononnon }\end{array}$ \\
\hline Plantains & $\begin{array}{l}\text { Adjangan, Aloga, } \\
\text { Mandangan, } \\
\text { Avlandjan }\end{array}$ & $\begin{array}{l}\text { Abidja, Aloga, } \\
\text { Avlandjangan, } \\
\text { Mandangan, } \\
\text { Gangnikokoué }\end{array}$ & $\begin{array}{l}\text { Agbavé, } \\
\text { Agoukokoué, } \\
\text { Djanvlan, } \\
\text { Gbavénon }\end{array}$ & $\begin{array}{l}\text { Abidja, } \\
\text { Adjangan, Aloga, } \\
\text { Mandangan, } \\
\text { Vlandjangan }\end{array}$ & $\begin{array}{l}\text { Agba, Avlan, } \\
\text { Aloga, Djanvlan, } \\
\text { Abidja }\end{array}$ & $\begin{array}{l}\text { Abidja, Aloga, } \\
\text { Djanvlan, } \\
\text { Gbavénon, } \\
\text { Adjangan }\end{array}$ & $\begin{array}{l}\text { Adjangan, } \\
\text { Agba, Agbavé, } \\
\text { Vlandjangan, Aloga }\end{array}$ \\
\hline
\end{tabular}

- Group 1 (G1) was composed of two cultivars which, according to the farmers, were low productivity but early cycle cultivars. This group was also made up of cultivars with a high resistance to drought, good for cooking, but susceptible to attack by BBTV.

- The group (G2) including the majority of plantain banana cultivars (12 cultivars) which were generally late cultivars with high productivity. In this group, we found cultivars with low post-harvest longevity that hence well for processing into other food product and deemed to be less susceptible to BBTV attacks.

\section{Constraints related to the production of bananas and plantains in the study area}

Several constraints were related to the production of bananas and plantains. Eleven major constraints affecting the production in our study area were identified and prioritized. The most important of these were the insect pest damages (13.42\% of responses), the drought, and the wind causing the lodging of the plants, each with a rate of $13.42 \%$ of responses. The second most important set of constraints were the excess of water, the insufficiency of arable lands, and the diseases such as Fusarium Race 1 and BBTV with a respective rate of $8.94 \%, 8.68 \%$, and $8.42 \%$ of mentions (Table 5).

\section{Cluster Dendrogram}

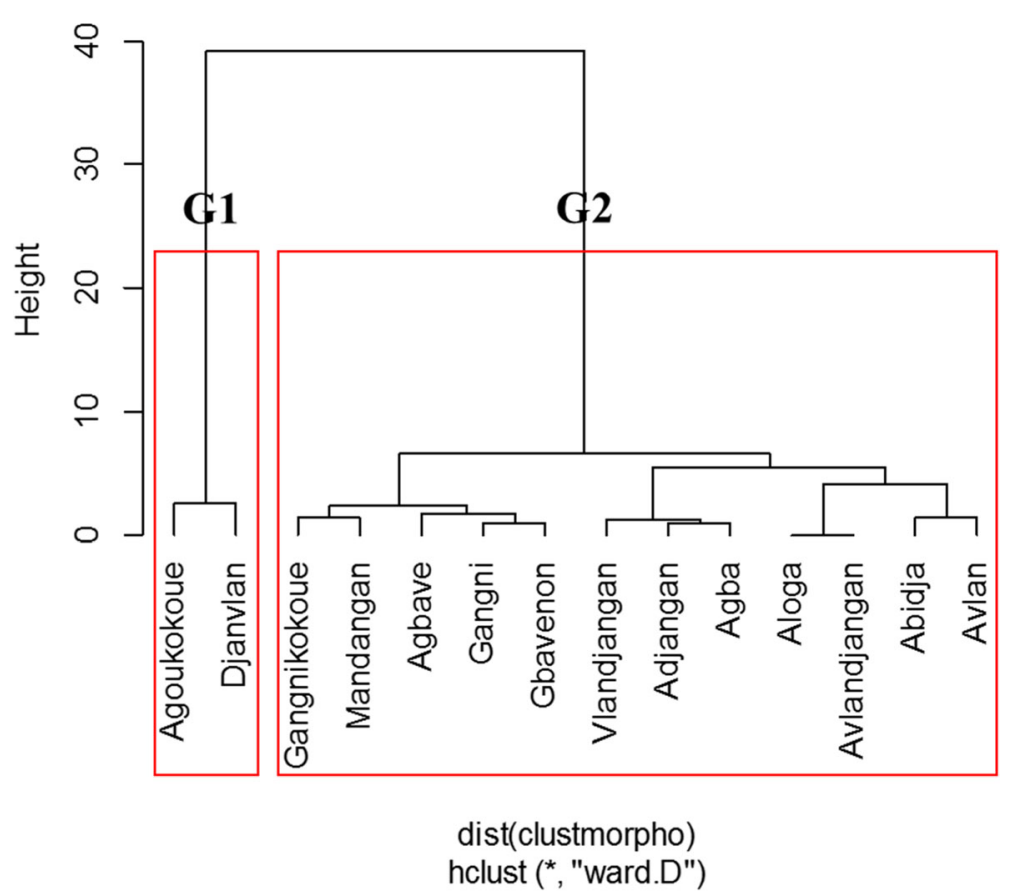

Fig. 10 Dendrogram of the classification of plantain cultivars according to agronomic characteristics. At the $70 \%$ of similarity, the different varieties of plantain were classified according to the importance of their production 
Table 5 Constraints related to the production of banana and plantain in South Benin

\begin{tabular}{|c|c|c|c|c|c|}
\hline Constraints & $\begin{array}{l}\text { Number of villages where } \\
\text { the constraint is quoted }\end{array}$ & $\begin{array}{l}\text { Number of villages in which } \\
\text { the constraint is ranked first }\end{array}$ & $\begin{array}{l}\text { Number of villages in which the } \\
\text { constraint is ranked in the top five }\end{array}$ & $\begin{array}{l}\% \text { of } \\
\text { responses }\end{array}$ & Rank \\
\hline Pest damages & 44 & 23 & 35 & 13.42 & 1 \\
\hline Drought & 45 & 14 & 43 & 13.42 & 2 \\
\hline Wind causing plant fall & 47 & 9 & 46 & 13.42 & 3 \\
\hline Excess water & 42 & 3 & 23 & 8.94 & 4 \\
\hline Insufficient cultivated field & 43 & 0 & 23 & 8.68 & 5 \\
\hline Viruses (BBTV and Fusarium Race1) & 46 & 1 & 17 & 8.42 & 6 \\
\hline Insufficient performing varieties & 42 & 0 & 18 & 7.89 & 7 \\
\hline Anthracnose & 32 & 1 & 19 & 6.84 & 8 \\
\hline Poverty of the soil & 42 & 0 & 8 & 6.57 & 9 \\
\hline Falling organs & 37 & 0 & 11 & 6.32 & 10 \\
\hline Low time of conservation & 38 & 0 & 8 & 6.05 & 11 \\
\hline
\end{tabular}

\section{Reasons for diversity losses of banana and plantain}

The reasons for diversity loss were assessed based on farmer's responses as to why they stopped growing or replaced named varieties they used to grow before. These can be grouped into two categories: agronomic reasons $(86.78 \%)$ and culinary and technological reasons (14.22\%). For agronomic reasons, the most important are the low productivity ( $28 \%$ of responses), the cycle length of some cultivars (15.58\% of responses), and the sensitivity to virus (12.52). The bitter taste (11.29\%) and poor processing of some local varieties $(7.82 \%)$ are the main reasons for the change of varietal diversity in the study area.

\section{Economic considerations}

During the surveys, we found that the selling price of the banana bunch varies constantly according to the different cultivars cultivated by farmers, the season, and bunch weight $(P<0.01)$ (Table 6$)$. The selling price of the banana bunch of cultivars such as Sovlan, Tchon, Alladakodou, and Chinouavi was significantly lower across all villages sampled, whereas cultivars such as Sotoumon, Amandan, and Planta were significantly more expensive (4000-4500 FCFA (7.00-7.90 dollars)). Regarding the selling price of the plantain bunch in the study area, some cultivars such as Agba, Agbavé, and Gbala were cheaper than others such as Adjangan, Avlandjangan, and Aloga (Table 7).

\section{Discussion}

This study identified 87 cultivars of banana and plantain in southern Benin. These identified local varieties are variously designated according to the local languages spoken in the study area. At the community level, each local variety has a local name by which it is identified, with each village its own name series. The same cultivar can therefore have several names at the zone level. Specific local naming [30] has already been reported on many crops, including traditional leafy vegetables [31, 32], yams [33, 34], cassava [35], fonio [20], and sorghum [36, 37]. The many synonyms and homonyms that exist in banana and plantain can often lead to an overestimation or an underestimation of the number of cultivars produced at the scale of the study area or country [38]. On this basis, it is unlikely that all local names of inventoried varieties are genetically distinct varieties, but provide a useful reference for future field collection in these regions nonetheless. Morphological and molecular characterizations would enable the

Table 6 Selling prices of banana cultivars according to farmers

\begin{tabular}{lll}
\hline Cultivars & Selling price of the regime (FCFA) & \% of farmers \\
\hline $\begin{array}{l}\text { Akodou, Akokoué, Akpahissi, Alladakodou, Allokokoué, Alokpoé, Amawiti, Chinouavi, Chon, } \\
\text { Cododé, Colèti, Dankodou, Danvlan, Djileké, Djoguodjigui, Edanmandan, Emènèotchoumaré, }\end{array}$ & 1500 \\
Fiossiké, Goukokoué, Kpafoukpafou, Sovlan, Tchon, Zodjagué & \\
$\begin{array}{l}\text { Assonwonnou, Atchakpoé, Dangni, Dimangnan, Emènè Olori, Emènèré, Gangnilo, Kodou, } \\
\text { Kinkoun, Kododoé, Kokoué, Kolédo, KokouéKoyou, Kokouéogouton, Olori, Tokpovi }\end{array}$ & 2000 \\
$\begin{array}{l}\text { Dangni, Dohèzè, Hohovikokoué, Sanmiénou, Sokokoué, Wontchimèssou } \\
\text { Amandan, Gnimangnan, Sodjèmi, Kpahounflo, Limovlan, Malikouè }\end{array}$ & 2500 \\
Hlogui, Jokosso, Ninkouin, Wontchimèssou & 3000 \\
Houngbo, Kpahissi, Kpafoutou, Kparata, Planta & 3500 \\
Sotoumon, Amandan, Ononnon & 4000 & 88.12 \\
\hline
\end{tabular}


Table 7 Selling prices of plantain cultivars according to farmers

\begin{tabular}{lll}
\hline Cultivars & $\begin{array}{l}\text { Selling price of } \\
\text { the regime (FCFA) }\end{array}$ & $\begin{array}{l}\text { \% of farmers } \\
\text { giving the prices } \\
\text { to these cultivars }\end{array}$ \\
\hline Abidjakokoue, Agba & 3000 & 96.64 \\
Agbave, Gangni & 3500 & 72.31 \\
Gbala, Agoukokoué & 4000 & 78.48 \\
Mandangan, Gbavenon & 4500 & 89.26 \\
Aloga, Avlan & 5000 & 94.77 \\
Avlandjangan, Djanvlan, & 5500 & 94.47 \\
Vlandjangan & & 85.73 \\
Adjangan & 6000 & \\
\hline
\end{tabular}

establishment of equivalence between names as was the case with other crops [39-41]. Indeed, the clarification of synonyms is a prerequisite for better management of the genetic resources of cultivated plants [42]. Besides, one banana variety grown in different regions may represent distinct somaclonal variants since banana seed sourcing is often local or within own farms. At the regional scale, the number of plantain cultivars is low in Benin compared to the 56 cultivars found in neighboring Togo [43].

Amongst the cultivars in our study area, the most popular were Sotoumon, Planta, and Dankokoue (banana) and Mandangan, Aloga, and Adjangan (plantain). These results constitute an important contribution to the documentation of the different denominations for banana and plantain in South Benin. They have also shown that in terms of taxonomy, banana nomenclature was based on the use of agronomic, morphological, and cultural traits. Nowadays, local people are moving towards botanical traits in the nomenclature and identification of cultivars and plant species [44]. This was previously reported by Agre et al. [42] that local communities name cultivars based on agro-morphological traits. The size, the shape, the color of the plants, the diets, and the fruits, as well as the characters of the pulp are all criteria which makes it possible to differentiate the varieties between them. Thus, amongst cooking bananas, plantains $(\mathrm{AAB})$ have a very firm orange pulp that is not found in other "cooking" banana plants. East African bananas (AAA) are very specific and used, depending on the clones, for dessert, cooking, or making beer. The flavors of dessert bananas are varied as well as their tastes: very sweet in certain diploid varieties, sweet-tart in Pomme-Figue (AAB), and neutral and universally appreciated in Cavendish (AAA) bananas intended for export $[45,46]$. The Adja, Aizo, and Goun ethnic groups hold more banana diversity than other ethnic groups. This is justified by the fact that these ethnic groups hold for years in their habits the production of several banana cultivars for traditional and therapeutic uses.
The major constraints related to the production of banana and plantain in South Benin are the damage by insect pests, drought, and wind. Producers reported good agricultural practices, such as planting in large holes for adequate root anchorage space, as effective. However, this was not always followed. The relatively low productivity of the available varieties was mentioned as a key problem. Low yield, poor tolerance to biotic and abiotic stress, and low score on post-harvest and processing quality of local cultivars were also identified and key impediments to production. Addressing these challenges through breeding and research would be important [32, $46,47]$. The diversity and distribution of banana and plantain cultivars varied from village to village. The cultivars cultivated by many households over large areas are not endangered and may simply be conserved in situ [20]. Those cultivated by few households in small areas deserve particular attention in terms of conservation. It would be important to collect and preserve them ex situ (including in vitro) [48]. For other cultivars cultivated by few households and on large areas and many households and few areas, the complementary approach (in situ and ex situ) will be necessary. However, approaches to increase tolerance to poor soils or agronomic practices aimed at improving the soil's potential are key short-term needs. Testing existing varieties under optimum ecological conditions may enable the appreciation of their true genetic potential [49-51].

The lowest pest damage was mentioned in the district where the diversity of banana cultivars was the highest. This finding may suggest that a high diversity of banana cultivars may contribute to the reduction in pest damages or that high levels of biotic challenges could result in a reduction of diversity (extirpation of varieties). Several mechanisms such as the concentration of resources and the repellent effects of some cultivars contribute to the reduction of pest damage by high diversity stands [52]. In banana and plantain production systems in southern Benin, farmers mix all the cultivated Musa cultivars on the same field making the system more complex. In this case, the concentration of resources can also confuse the pest on the choice of the type of cultivar to be consumed in this mixed system of banana and plantain [53]. This result might also be explained by those areas simply being richer agriculturally and so enabling plants to tolerate pest attack and sustain some level of production.

The first farmer preference criterion for cultivars in the study area is high productivity linked to the high bunch weight. The precocity of the cycle, good taste of bananas, and the size of the fruits are main criteria of preference of the banana cultivars. Indeed, in this study, banana cultivars are firstly preferred for their food uses in particular the sweet taste and also it is one of the 
fruits which, because of its short cycle, brings more income to the producers in order to meet the family needs. Selection or creation programs must therefore be put in place to increase the production of banana and plantain and contribute to the increase in farmers' incomes. The importance attached to the size, nutritional quality, and sweet fruits of plantain confirms the preference given by farmers to the cultivars. The different preference criteria thus identified and prioritized must be taken into account by breeding programs in order for these new varieties to be adopted.

\section{Conclusion}

The diversity and cultivar richness of banana and plantain in southern Benin is highly variable per location. Random factors and systematic selection through preference, use, and seed sharing contribute this variation. Some of these cultivars are extremely rare and may require special attention to preserve their genetic endowments. The main reasons for their disappearance are related to drought sensitivity, poor soil tolerance, low productive value and low market value of some cultivars. The names of the varieties varying from one ethnic group to another or from one village to another within the same ethnic group and an agro-morphological and nucleic acid characterization will have to be made to clarify the duplicates. The high price and inadequate supply of planting materials is a hindrance to diversity, cultivar distribution, and the growth of banana production in Benin.

\section{Abbreviations}

BBTD: Banana bunchy top disease; BBTV: Banana bunchy top virus; BIORAVE: Biotechnology, Genetic Resources and Plant and Animal Breeding; FAO: Food and Agriculture Organization; FCFA: Francs Colonies Françaises d'Afrique; GLMs: Generalized linear models; KIl: Key informant interviews

\section{Acknowledgements}

This work is part of Master thesis of Mariano Chabi and was funded by BIORAVE. We thank banana and plantain farmers in Southern Benin who unconditionally accepted to respond to interviews and to make available their fields for observations. BAO's time was supported by the CGIAR-

Programme on Roots Tubers and Bananas through Bioversity International.

\section{Funding}

BIORAVE funded field activities including field materials and field visit travels.

\section{Availability of data and materials}

Data generated during this study are available from the corresponding author.

\section{Authors' contributions}

MCC, AGD, AD, BOA, and IDA participated in the study design; they analyzed and interpreted the data and drafted the manuscript. MCC, DO, and AGD carried out the field surveys. AGD, MCC, DO, BOA, and AD corrected the manuscript. All authors approved the final manuscript.

\section{Ethics approval and consent to participate}

Not applicable.

\section{Consent for publication}

Not applicable.

\section{Competing interests}

The authors declare that they have no competing interests.

\section{Publisher's Note}

Springer Nature remains neutral with regard to jurisdictional claims in published maps and institutional affiliations.

\section{Author details}

${ }^{1}$ Laboratory of Biotechnology, Genetic Resources and Plant and Animal Breeding, National University of Sciences, Technologies, Engineering and Mathematics, BP: 14, Dassa, Benin. 'Bioversity International, IITA Campus Abomey-Calavi, 08 BP Tri Postal 0932, Cotonou, Benin.

Received: 21 August 2018 Accepted: 3 December 2018

Published online: 14 December 2018

\section{References}

1. Lassoudière A. Le bananier et sa culture. editions Quae; 2007.

2. Teycheney PY, Acina I, Lockhart BE, Candresse T. Detection of Banana mild mosaic virus and Banana virus $\mathrm{X}$ by polyvalent degenerate oligonucleotide RT-PCR (PDO-RT-PCR). J Virol Methods. 2007;142(1-2):41-9.

3. FAO. FAOSTAT database. Roma: Food and Agriculture Organization; 2013. http://www.fao.org/home/en/. Accessed 12 Mar 2018.

4. Kitavi M, Downing T, Lorenzen J, Karamura D, Onyango M, Nyine M, Ferguson M, Spillane C. The triploid East African Highland Banana (EAHB) genepool is genetically uniform arising from a single ancestral clone that underwent population expansion by vegetative propagation. Theor Appl Genet. 2016;129(3):547-61.

5. Karamura EB, Karamura DA. Banana morphology — part II: the aerial shoot. In: Bananas and plantains. Dordrecht: Springer; 1995. p. 190-205.

6. Karamura E, Frison E, Karamura DA, Sharrock S. Banana production systems in eastern and southern Africa. Bananas and food security. Montpellier: INIBAP; 1998. p. 401-12.

7. Ortiz R. Morphological variation in Musa germplasm. Genet Resour Crop Evol. 1997:44(5):393-404.

8. Pillay M, Ogundiwin E, Nwakanma DC, Ude G, Tenkouano A. Analysis of genetic diversity and relationships in East African banana germplasm. Theor Appl Genet. 2001;102(6-7):965-70.

9. Simmonds NW, Shepherd K. The taxonomy and origins of the cultivated bananas. Bot J Linean Soc. 1955;55(359):302-12.

10. Lokossou B, Affokpon A, Adjanohoun A, Dan CBS, Mensah GA. Evaluation des variables de croissance et de développement du bananier plantain en systèmes de culture associée au Sud-Bénin, Bulletin de la recherche agronomique du Bénin; 2012. p. 1-8.

11. Soule B. Politique agricole de la CEDEAO: la monographie du Bénin. Cotonou; 2012. p. 1-24. http://www.slire.net/download/1530/polacedeao. pdf.

12. Rabbani GH, Teka T, Saha SK, Zaman B, Majid N, Khatun M, Fuchs GJ. Green banana and pectin improve small intestinal permeability and reduce fluid loss in Bangladeshi children with persistent diarrhea. Dig Dis Sci. 2004;49(3):475-84.

13. Sarawong C, Schoenlechner R, Sekiguchi K, Berghofer E, Ng PK. Effect of extrusion cooking on the physicochemical properties, resistant starch, phenolic content and antioxidant capacities of green banana flour. Food Chem. 2014;143:33-9.

14. De Souza GC, Haas APS, Von Poser GL, Schapoval EES, Elisabetsky E. Ethnopharmacological studies of antimicrobial remedies in the south of Brazil. J Ethnopharmacol. 2004:90(1):135-43.

15. Aho N, Kossou D. Précis d'agriculture tropicales: bases et éléments d'application. Les éditions du Flamboyant (Cotonou, R. du Bénin), vol. 33; 1997. p. $45-360$

16. Côte $F X$, Teisson C, Perrier $X$. Somaclonal variation rate evolution in plant tissue culture: contribution to understanding through a statistical approach. In Vitro Cell Dev Biol Plant. 2001;37(5):539-42.

17. Läderach $P$, Oberthür T, Cook S, Iza ME, Pohlan JA, Fisher M, Lechuga RR. Systematic agronomic farm management for improved coffee quality. Field Crops Res. 2011;120(3):321-9.

18. Yao X, Deng J, Huang H. Genetic diversity in Eucommia ulmoides (Eucommiaceae), an endangered traditional Chinese medicinal plant. Conserv Genet J. 2012;13(6):1499-507. 
19. Dansi A, Adoukonou-Sagbadja H, Vodouhe R. Diversity, conservation and related wild species of Fonio millet (Digitaria spp) in the northwest of Benin. Genet Resour Crop Evol. 2010;57:827-39.

20. Adomou AC, Sinsin B, Van der Maesen LJG. Notulae florae beninensis 12: phytosociological and chorological approaches to phytogeography: a meso-scale study in Benin. Syst Geogr Plants. 2006;7:155-78.

21. Gnanglè CP, Glèlè Kakaï R, Assogbadjo AE, Vodounnon $S$, Afouda Yabi J, Sokpon N. Tendances climatiques passées, modélisation, perceptions et adaptations locales au Bénin. Climatologie. 2011;8:27-40

22. Kumar K. Conducting key informant interviews in developing countries. Washington DC: Agency for International Development; 1989. p. 1-40.

23. Dansi A, Dantsey-Barry H, Dossou-Aminon I, Kpenu EK, Agré AP, Sunu YD, Assogba P. Varietal diversity and genetic erosion of cultivated yams (Dioscorea cayenensis Poir-D. rotundata Lam complex and D. alata L.) in Togo. Int J Biodivers Conserv. 2013;5(4):223-39.

24. Orobiyi A, Dansi M, Assogba P, Loko LY, Vodouhe R, Akouegninou A, Sann A. Chili (Capsicum annuum L.) in southern Benin: production constraints, varietal diversity, preference criteria and participatory evaluation. Int Res J Agr Sci Soil Sci. 2013;3(4):107-20.

25. Kumar PL, Hanna R, Alabi OJ, Soko MM, Oben TT, Vangu GHP, Naidu RA. Banana bunchy top virus in sub-Saharan Africa: investigations on virus distribution and diversity. Virus Res. 2011;159(2):171-82.

26. Davis FM, Ng SS, Williams WP. Visual rating scales for screening whorl-stage corn for resistance to fall armyworm, Mississippi Agricultural \& Forestry Experiment Station; Technical Bulletin; 1992. p. 186.

27. Shannon CA. Mathematical theory of communication. Bell Syst Tech J. 1948; 27:379-423.

28. Oksanen J, Blanchet FG, Kindt R, Legendre P, Minchin PR, O'hara RB \& Wagner H. Vegan: community ecology package. R package version. 2015;2.2-1. 2015.

29. R Development Core Team. R: a language and environment for statistical computing. Vienna: R Fundation for Statistical Computing; 2012.

30. Bhuwon S, Abhishek S, Devra J, Hugo L, Ramanatha RV. Community based approach to on-farm conservation and sustainable use of agricultural biodiversity in Asia. Indian J Plant Genet Resour. 2012;25:97-110.

31. Adjatin A, Dansi A, Eze CS, Assogba P, Dossou-Aminon I, Akpagana K, Akoegninou A, Sanni A. Ethnobotanical investigation and diversity of Gbolo (Crassocephalum rubens (Juss. ex Jacq.) S. Moore and Crassocephalum crepidioides (Benth.) S. Moore), a traditional leafy vegetable under domestication in Benin. Genet Resour Crop Evol. 2012:59:1867-81.

32. Gbèdolo AE, Dassou AG, Dassou HG, Aminon ID, Omondi BA, Dansi A. Morphotype diversity of Corchorus olitorius and influence of agricultural practices on its potential major pest insects. Sci Hort. 2018;239:234-41.

33. Tamiru M, Becker HC, Maass BL. Diversity, distribution and management of yam landraces (Dioscorea spp.) in Southern Ethiopia. Genet Resour Crop Evol. 2008;55(1):115-31.

34. Loko YL, Dansi A, Agre AP, Akpa N, Dossou-Aminon I, Assogba P, Dansi M, Akpagana K, Sanni A. Perceptions paysannes et impacts des changements climatiques sur la production et la diversité variétale de l'igname dans la zone aride du nord-ouest du Bénin. Int J Biol Chem Sci. 2013;7:672-95.

35. Kombo GR, Dansi A, Loko LY, Orkwor GC, Vodouhè R, Assogba P, Magema JM. Diversity of cassava (Manihot esculenta Crantz) cultivars and its management in the department of Bouenza in the Republic of Congo. Genet Resour Crop Evol. 2012;59:1789-803.

36. Dossou-Aminon I, Loko LY, Adjatin A, Dansi A, Elangovan M, Chaudhary P, Vodouhè R, Sanni A. Diversity, genetic erosion and farmer's preference of sorghum varieties [Sorghum bicolor (L.) Moench] in North-Eastern Benin. Int J Curr Microbiol App Sci. 2014;3(10):531-52.

37. Mekbib F. Infra-specific folk taxonomy in sorghum (Sorghum bicolor (L.) Moench) in Ethiopia: folk nomenclature, classification, and criteria. J Ethnobiol Ethnomed. 2007;3(1):38.

38. Tsehaye Y, Abera Z, Kebede A, Ghebremichael B. A dynamic sorghum (Sorghum bicolor (L.) Moench) diversity management in situ and livelihood resilience in South and Central Tigray Region, Ethiopia. Momona Ethiop J Sci. 2009;1:67-94.

39. Dossou-Aminon I, Loko LY, Adjatin A, Ewédjè EEB, Dansi A, Rakshit $S$, Akoègninou A. Genetic divergence in Northern Benin Sorghum (Sorghum bicolor L. Moench) landraces as revealed by agromorphological traits and selection of candidate genotypes. Sci World J. 2015;2015:916476. https://doi. org/10.1155/2015/916476.
40. Dansi A. Collecting vegetatively propagated crops (especially roots and tubers) In: Guarino L, Ramanatha Rao V, Goldberg E, editors. Collecting plant genetic diversity: technical guidelines - 2011 update. Rome: Bioversity International; 2011. ISBN 978- 92-9043- 922- 6. http://cropgenebank.sgrp.cgiar.org.

41. Chakanda R, van Treuren R, Visser B, van den Berg R. Analysis of genetic diversity in farmers' rice varieties in Sierra Leone using morphological and AFLP markers. Genet Resour Crop Evol. 2012;60:1237-50.

42. Agre AP, Rabbi IY, Battachargee R, Becerra López Lavelle LA, Sanni A, Akouegninou A, Akpagana K. A gromorphological characterization of elite cassava (Manihot esculenta Crantz) cultivars collected in Benin. Int J Cur Res Biosci Plant Biol. 2015;2(2):1-14.

43. Koukouma R, Yedomanhan H, Dansi A, Adjatin A, Agre P. Diversity and management of banana and plantain (Musa spp.) varieties in Togo. Int J Curr Res Biosci Plant Biol. 2016;3(2):127-38.

44. de Langhe E. La taxonomie du bananier plantain en Afrique Equatoriale. Journal d'Agriculture Tropicale et de Botanique Appliquée. 1961;8:417-49.

45. Abdel-Fatah BE, Ali EA, El-Din AT, Hessein EM. Genetic diversity among Egyptian sorghum (Sorghum bicolor L. Moench) landraces in agro-morphological traits and molecular markers. Asian J Crop Sci. 2013;5:106-24.

46. Sawadogo M, Balma D. Etude agromorphologique de quelques écotypes locaux de gombo cultivés au Burkina Faso. Sci Tech. 2003;27(1-2):111-29.

47. Bakry F, Carreel F, Jenny C, Horry JP. Genetic improvement of banana. Breeding plantation tree crops: tropical species; 2009. p. 3-50.

48. Kagy $\mathrm{V}$, Wong $\mathrm{M}$, Vandenbroucke $\mathrm{H}$, Jenny $\mathrm{C}$, Dubois $\mathrm{C}$, Olivier $\mathrm{A}$, et al. Traditional banana diversity in Oceania: an endangered heritage. PLoS One. 2016:11(3):e0151208.

49. Carreel F, Fauré S, De Leon DG, Lagoda PJL, Perrier X, Bakry F, Tezenas du Montcel $H$, Lanaud C, Horry JP. Evaluation de la diversité génétique chez les bananiers diploïdes (Musa sp). Genet Sel Evol. 1994;26(1):S125.

50. Aigbe SO, Remison SU. Cultivars planted in different agro-ecological environments. Asian J Plant Pathol. 2010;4(2):82-9.

51. Adjei-Nsiah S. Role of pigeonpea cultivation on soil fertility and farming system sustainability in Ghana. Int J Agron. 2012:702506. https://doi.org/10. 1155/2012/702506.

52. Ratnadass A, Fernandes P, Avelino J, Habib R. Plant species diversity for sustainable management of crop pests and diseases in agroecosystems: a review. Agron Sustain Dev. 2012;32(1):273-303.

53. Dassou GA, Dépigny S, Canard E, Vinatier F, Carval D, Tixier P. Contrasting effects of plant diversity across arthropod trophic groups in plantain-based agroecosystems. Basic Appl Ecol. 2016;17(1):11-20.

\section{Ready to submit your research? Choose BMC and benefit from:}

- fast, convenient online submission

- thorough peer review by experienced researchers in your field

- rapid publication on acceptance

- support for research data, including large and complex data types

- gold Open Access which fosters wider collaboration and increased citations

- maximum visibility for your research: over $100 \mathrm{M}$ website views per year

At $\mathrm{BMC}$, research is always in progress.

Learn more biomedcentral.com/submission 